${ }^{\circledR}$ Entomologica Fennica. 8 January 1998

\title{
First record of North American ambrosia beetle Gnathotrichus materiarius (Fitch) (Coleoptera, Scolytidae) in Finland - a new potential forest pest?
}

\author{
Heli Valkama, Petri Martikainen \& Mika Räty
}

\begin{abstract}
Valkama, H., Martikainen, P. \& Räty, M. 1998: First record of North American ambrosia beetle Gnathotrichus materiarius (Fitch) (Coleoptera, Scolytidae) in Finland - a new potential forest pest? - Entomol. Fennica 8: 193-195.

The North American ambrosia beetle Gnathotrichus materiarius is reported for the first time in Finland. One specimen was caught by a Ips typographus pheromone trap in Vantaa in 1996. The species was introduced to Europe from North America in 1933, and since then it has spread to many Middle European countries. It is possible that this species has already become established in Fennoscandia, because of repeated introductions.
\end{abstract}

Heli Valkama, Petri Martikainen \& Mika Räty, Faculty of Forestry, University of Joensuu, P.O. Box 111, FIN-80101 Joensuu, Finland

Received 12 February 1997, accepted 30 September 1997

\section{Record}

The first record of the originally North American ambrosia beetle Gnathotrichus materiarius (Fitch) in Finland was made during the Ips typographus $\mathrm{L}$. pheromone trapping survey in Southern Finland in 1996 (Valkama et al. 1997). In the survey, beetles were caught with drainpipe traps (1979 model) baited with Ipslure ${ }^{\circledR}$ plastic bag dispensers (Bakke et al. 1983). The survey was conducted 6.V.27.VII.1996 in nine localities between Nauvo in SW Finland and Harlu in Russian Karelia. In each locality, a group of three traps was placed $50 \mathrm{~m}$ from an adjacent forest edge. One specimen of $G$. materiarius was caught from $N$ : Vantaa, Vestra (6692:376) 25.VI.-27.VII.1996. The trapping site was a previous winter clear-cut area previously dominated by Norway spruce (Picea abies (L.) Karst.).

\section{Expansion in Europe}

G. materiarius originates from eastern North America. In Canada the species occurs in New Brunswick, Nova Scotia, Ontario and Quebec, and the USA range covers South Dakota, Maine and Florida, and towards Texas and Nebraska (Baker 1972, Wood 1982).

The species was introduced into Europe for the first time in 1933 in France (Balachowsky 1949). Since then, it has become established in many Middle European countries. It was found in Germany in 1964 (Gladitsch 1969) and in the Netherlands in 1965 (Doom 1967). Latest notes about establishment are from Switzerland in 1984-1988 (von Hirschheydt 1992) and from Northern Germany near Hamburg (Lohse \& Lucht 1994). Von Hirschheydt (1992) presented a detailed list and a map of records in Europe.

\footnotetext{
* Communicated at the meeting of the Entomological Society of Finland 17.1.1997.
} 
Until now, the only records of G. materiarius from Fennoscandia are from Sweden, where the species has been found in Pinus pinaster Ait. twice: once in pulpwood imported from France or Spain (Gillerfors 1988) and the second time in French unbarked roundwood logs (Schroeder 1990). There are no previous records of the species from Finland, not even as an imported species (I. Mannerkoski \& H. Silfverberg, pers. comm.).

\section{Ecology}

The body of $G$. materiarius is less than $3.5 \mathrm{~mm}$ long, nearly cylindrical, smooth and dark reddish brown to blackish brown. The head is blackish and fine punctured and antennae with the club 1.5 times as long as the shaft (Doom 1967, Freude et al. 1981). The species is an ambrosia beetle which cultures in its galleries the fungus Endomycopsis fasciculata Batra that the larvae feed on (Postner 1974). The galleries resemble those in Trypodendron lineatum (Oliv.), although they are narrower, only $1 \mathrm{~mm}$ in diameter (Doom 1967). As the English name Eastern Pine Wood-Stainer indicates, the species lives mainly on pines, but feeds in America also on Abies, Picea, Larix, Tsuga and Thuja (Blackman 1931, Balachowsky 1949). From Europe the species has been recorded on Pinus, Picea, Larix, Pseudotsuga and Abies (Doom 1967, von Hirschheydt 1992). Most of the European records document $G$. materiarius from already dead or felled trees, so damage caused by the species has been mainly technical due to larval galleries and black discoloration caused by associated fungi (Doom 1967, Postner 1974). In southern parts of the USA, especially pines killed by $I p s$ bark beetles are often attacked by the species (Baker 1972). Swarming takes place in Germany between the end of April and middle of June (Gauss 1971, Postner 1974).

\section{Discussion}

Since the first specimen in Finland was caught in normal managed forest with the pheromone trap, we are not able to determine the original source of the species. It is possible that the specimen is imported, because large amounts of conifer rawwood were imported to Finland, e.g. from Canada, France, Germany and other European Union countries during the years 1995-1996 (Ulkomaankauppa 1995 ... 1996). The distance between the trapping site and the nearest harbor is about $25 \mathrm{~km}$. However, it is also possible that the species has already been breeding in the region.

It is difficult to assess whether the species is able to become established in Finland and other Nordic countries. The distribution of G. materiarius in northern parts of North America covers partly areas where the bioclimatic conditions are comparable to those in some areas in the boreal zone in Fennoscandia (Hämet-Ahti 1970). The species has been recorded also inhabiting high altitudes (800-1 000 m) in France, Germany and Switzerland (von Hirschheydt 1992), which may suggest the ability of the species to tolerate the climatic conditions of Fennoscandia. In the case that the species can survive in our climate, it is likely that it has already become established in some parts of Fennoscandia because of repeated introductions. However, many other factors besides climate are involved in the success of an introduced species (Siitonen 1990, Niemelä \& Mattson 1996). The nature of the current finding suggests that a considerable number of $G$. materiarius-individuals have been swarming in Vantaa in the summer 1996. It is not very probable that we have succeeded in catching the only specimen in the region.

We also surveyed the occurrence of $G$. materiarius in several localities in the Vantaa and Helsinki areas (including the original locality in Vestra) in the summer 1997 by pheromone traps baited with $G$. sulcatus and $G$. retusus pheromones. No specimens of $G$. materiarius were found in this survey. However, further monitoring is needed to clarify whether the species is already established in Finland.

Acknowledgements. We thank Stig Lundberg for the identification of the species. Erik Christiansen and Martin Schroeder gave valuable information on the species in Norway and Sweden. Jari Kouki and Pekka Niemelä helped to review the manuscript. 


\section{References}

Baker, W. L. 1972: Eastern forest insects. - U.S. Department of Agriculture, Forest Service. Miscellaneous Publication No. 1175. 642 pp.

Bakke, A., Sæther, T. \& Kvamme, T, 1983: Mass trapping of the spruce bark beetle Ips typographus. Pheromone and trap technology. - Medd. Nor. inst. skogforsk. 38: 1-35.

Balachowsky, A. 1949: Coléoptères Scolytides. — Faune de France 50: 1-320.

Blackman, M. W. 1931: A revisional study of the genus Gnathotrichus Eichhoff in North America. - J. Wash. Acad. Sci. 21: 264-276.

Doom, D. 1967: Notes on Gnathotrichus materiarius (Col. Scolytidae), a timber beetle new to the Netherlands. Entomol. Ber. (Amsterdam) 27: 143-148.

Freude, H., Harde, K. W. \& Lohse, G. A. 1981: Die Käfer Mitteleuropas. Band 10. Bruchidae, Anthribidae, Scolytidae, Platypodidae, Curculionidae. — Goecke \& Evers Verlag, Krefeld, Germany. 310 pp.

Gauss, R. 1971: Eingeschleppter Nutzholzborkenkäfer bedroht unser Nadelholz. -- Allg. Forstztschr. 26: $469-471$.

Gillerfors, G. 1988: Skalbaggar införda till Sverige med importerad massaved. - Entomol. Tidskr, 109: 42-45.

Gladitsch, S. 1969: Neue Beobactungen über den eingeschleppten Scolytiden Gnathotrichus materiarius FITCH. - Mitt. Entomol. Ver. Stuttgt. 4: 76-78.

Hämet-Ahti, L. 1970: Bioklimaattisesti Suomea vastaavista alueista. - Dendrologian Seuran Tiedotuksia 4: 2-11.

Lohse, G. A. \& Lucht, W. H. 1994: Die Käfer Mitteleuropas.
3. Supplementband mit Katalogteil. — Goecke \& Evers Verlag, Krefeld, Germany. 403 pp.

Niemelä, P. \& Mattson, W. J. 1996: Invasion of North American forests by European phytophagous insects. Legacy of European crucible? - BioScience 46: 741-753.

Postner, M. 1974: Scolytidae Borkenkäfer, —In: Schwenke, W. (ed.), Die Forstschädlinge Europas. Bd 2. Käfer: 334 482. Verlag Paul Parey, Hamburg und Berlin. 500 pp.

Schroeder, L. M. 1990: Occurrence of insects in coniferous roundwood imported to Sweden from France and Chile. - EPPO Bulletin 20: 591-596.

Siitonen, J. 1990: Potential forest pest beetles conveyed to Finland on timber imported from the Soviet Union. Silva Fennica 24: 315-321.

Ulkomaankauppa tammikuu 1995 ... heinäkuu 1996. 1A. Kuukausijulkaisu. Suomen virallinen tilasto. (Foreign Trade January 1995 ... July 1996. 1A. Monthly Bulletin. Official Statistics of Finland.) - Tullihallitus. (National Board of Customs, Finland.) (In Finnish.)

Valkama, H., Räty, M. \& Niemelä, P. 1997: Catches of Ips duplicatus and other non-target Coleoptera by Ips typographus pheromone trapping. - Entomol. Fennica 8: $153-159$

von Hirschheydt, J. 1992: Der Amerikanische Nutzholzborkenkäfer Gnathotrichus materiarius (FITCH) hat die Schweiz erreicht. - Mitt. Schweiz. Entomol. Gesell. 65: 33-37.

Wood, S. L. 1982: The Bark and Ambrosia Beetles of North and Central America (Coleoptera: Scolytidae), a Taxonomic Monograph. - Great Basin Naturalist Memoirs, No 6. Brigham Young University, Provo, Utah. $1359 \mathrm{pp}$. 